\title{
WISSELING IN HET PAVILJOEN \\ $N O$-THEATER KOSTUUMS UIT DE COLLECTIE VAN HET OKURA MUSEUM OF ART
}

\begin{abstract}
Dit jaar is het 45 jaar geleden dat Hotel Okura in Amsterdam werd geopend, als eerste vestiging van het bedrijf buiten Japan. Ter gelegenheid hiervan is er in het najaar een opstelling uit de collectie van het Okura Museum of Art (Tokyo) te zien in het Paviljoen, van zeven kostuumstukken van het no-theater. Het is een kleine groep die toch de moeite van de reis waard is, want het komt niet vaak voor dat spectaculaire stukken van deze kwaliteit in Nederland getoond worden. Hieronder vindt u een beknopte catalogus met inleiding.
\end{abstract}

\section{Het Okura Museum of Art}

Het Okura Museum of Art werd in I9I7 opgericht en was toen het eerste privémuseum in Japan. Het huisvestte de collectie van Okura Kihachiro (I837-I928), een zakenman van eenvoudige afkomst die in I855, vlak na de openstelling van Japan, vanuit de provincie naar Tokyo was getrokken om daar de levensmiddelenhandel Okuraya te beginnen. In de jaren I860 begaf hij zich ook in buitenlandse handel, werd toeleverancier voor het leger en breidde zijn handelsmaatschappij uit naar allerlei gebieden. In de laatste decennia van de $19^{\mathrm{e}}$ eeuw groeide de firma uit tot een succesvol conglomeraat van bedrijven: de Okura zaibatsu. Het werd een van de succesvolle grote bedrijvengroepen van de vroege $20^{\mathrm{e}}$ eeuw, samen met andere giganten als Mitsui, Sumitomo en Mitsubishi.

Net als zijn tijdgenoten zag Okura het belang van goed functionerende instellingen voor een land en richtte hij in I9oo de Okura Commercial School op, de huidige Tokyo University of Economics. In I9I5 werd hij verheven tot baron (danshaku) voor zijn verdiensten. Het museum dat hij twee jaar later stichtte was een groot houten gebouw van meerdere verdiepingen, dat helaas slecht bestand bleek tegen de catastrofale aardbeving van 1923. Een groot deel van de collectie ging verloren, maar het museum werd in 1927 herbouwd en het betonnen gebouw in traditionele stijl met een karakteristiek bronzen dak is inmiddels beschermd cultureel erfgoed.

Evenals zijn mede-industriëlen had Okura Kihachiro een brede belangstelling voor cultuur, waaronder de podiumkunsten. In I886 was hij bij de oprichters van het genootschap dat het kabuki-theater beoogde te vernieuwen. ${ }^{1}$ Ook zijn zoon Kishichiro hield zich op cultureel vlak bezig. Hij was onder meer een actief go-speler. Terwijl zijn vader verantwoordelijk was voor het bijeenbrengen van de oude kunstvormen, zoals de boeddhistische beeldhouw- en schilderkunst, vormde Kishichiro de collectie hedendaagse schilderkunst in Japanse stijlowaar het museum 06:50:52Am 
nu om bekend staat. Deze schilderkunst vormde de kern van de tentoonstelling van de Okura collectie die in 1930 onder de auspiciën van de Italiaanse overheid werd gehouden in Rome.

De no-kostuums van de Okura familie zijn afkomstig uit het bezit van de daimyo van het domein Bizen in Okayama, de Ikeda-clan, en waarschijnlijk werden ze grotendeels bijeengebracht door de vijfde generatie Ikeda Harumasa (I750-I8I8). Het is mooi dat de collectie bijeen is gebleven en het museum nu een representatief overzicht kan bieden van de kledingstukken van deze traditionele toneelvorm.

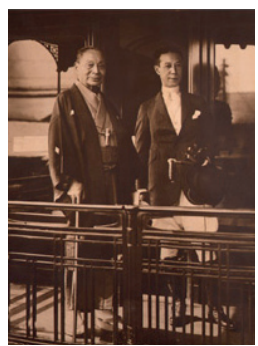

Afb. 1

Okura Kihachiro en zijn zoon Kishichiro

\section{Het no-theater}

Het no-theater ontwikkelde zich tegen het eind van de $\mathrm{I}^{\mathrm{e}}{ }^{\mathrm{e}}$ eeuw onder shogun Yoshimitsu (I358-I408), die het werk steunde van Kan'ami (I333I384) en zijn zoon Zeami (I363-I443). Zij legden als acteurs, toneelschrijvers en theoretici de basis voor deze buitengewoon gestileerde Japanse toneelvorm, waarin zang, muziek en dans samenkomen. Vooral Zeami perfectioneerde de kunstvorm. Erika de Poorter (I943-20I4), de japanologe die haar carrière wijdde aan het no-theater, vatte het zo samen:
De acteurs, aldus Zeami, moeten geen realistische uitbeelding geven van de gebeurtenissen. Ze moeten met dans, gebarenspel en poëzie in de tekst schoonheid creëren op het podium en de toeschouwers daarvan laten genieten. Die schoonheid noemt hij yugen. Dit was een esthetisch ideaal in de tijd dat no ontstond. De oorspronkelijke betekenis van dit woord in het Chinees was 'vaag en diep', 'ondoorgrondelijk'. [...] In Zeami's theoretische verhandelingen over no heeft yugen de betekenis van een schoonheid die gepaard gaat met elegantie, zachtheid en rust. ${ }^{2}$

De boeddhistische kijk op de wereld als een plek van vergankelijkheid, lijden en het zoeken naar verlossing is sterk in de thematiek in het notheater. De acteurs beelden rollen uit als intermediair tussen de werelden van de goden en mensen. Begeleid door muziek en zang voeren de bijrol (waki), vaak een priester, en de hoofdrol (shite) een dans op waarvan iedere beweging is voorgeschreven. De hoofdfiguur zoekt bemiddeling bij de waki en verkrijgt die ten slotte. Uiteindelijk kan de hoofdfiguur, bevrijd van het karma waaronder hij of zij te lijden had, het toneel weer verlaten.

Aan het einde van de $\mathrm{I} 6^{\mathrm{e}}$ eeuw en in $\mathrm{I} 7^{\mathrm{e}}$ eeuw vonden $n o$-acteurs patronage bij de heersende klasse van de krijgsadel. De shogun en de hogere samuraiklasse subsidieerden toneelgezelschappen en lieten hen bij speciale gelegenheden in hun residentie optreden. Ook Ikeda Harumasa was een hooggeplaatste functionaris in het landsbestuur. Als hofmaarschalk en thesaurier bij het shogunaat had hij een positie dicht bij het centrum van de macht en zal zijn affiniteit met het no-theater goed van pas zijn gekomen.

In de loop van de $\mathrm{I} 7^{\mathrm{e}}$ eeuw vond er een verregaande regulering van no plaats. De programmering van de stukken, de structuur van de gezelschappen en de opvoeringspraktijk werden in vaste vormen gegoten, die daarna weinig verandering hebben ondergaan Een van $_{1}$ dectrends/ die 06:50:52Am 
toen is ingezet en die tot op de dag van vandaag voortduurt, is dat het no steeds plechtiger en ingetogener is gaan worden en dat, wellicht als gevolg daarvan, het tempo van opvoeren steeds trager wordt. Zo denkt men dat een opvoering die in de tijd van Zeami nog geen 25 minuten duurde, nu een uur nodig heeft.

\section{Kostuums voor het no-theater}

No-kostuums reflecteren de herkomst van no onder de bovenlaag van de bevolking. De kleurrijke, kostbare gewaden werden oorspronkelijk bij speciale gelegenheden gedragen door de elite binnen de samurai-klasse. In de begintijd waren no-kostuums identiek aan de kleding van de elite en er zijn gevallen bekend waarbij kledingstukken als geschenk werden gegeven aan toneelgezelschappen. De meeste soorten die nu nog worden gebruikt hebben hun oorsprong in de kleding van de late $\mathrm{I}^{\mathrm{e}}$ eeuw. Met de regulering in $\mathrm{de}_{1} 7^{\mathrm{e}}$ eeuw werden ook de kostumering vastgelegd en aangezien no-kostuums vanaf toen niet meegingen met ontwikkelingen in de mode voor kimono's is het vaak lastig om ze te dateren. In de bloeiende stadscultuur veranderde bijvoorbeeld de breedte van de ceintuur (obi) voortdurend, maar bleef de obi voor no onveranderd smal. Ook nieuwe technieken vonden geen ingang, zoals de yuzen-methode om patronen te verven, ${ }^{3}$ ook al omdat die techniek geassocieerd werd met de lagere klasse van kooplieden.

De indeling van no-kostuums is deels naar het type van het kledingstuk, zoals de kortere overjassen kariginu (cat. I) en choken (cat. 7), of de broekrok hangiri (cat. 2). De lange kimono's zijn van het kosode-model, met aan het eind van de mouw relatief smalle openingen voor de handen. De hangende kant van de mouw is naar de opening toe rond gevormd. Bij no-kostuums worden ze ingedeeld aan de hand van de techniek van weven en versieren. In de kleine selectie die nu wordt getoond zijn alleen de types nuihaku (cat. 3 en 4) en karaori (cat. 5 en 6) vertegenwoordigd. Samen geven ze een indruk van de kleurrijke sfeer die tijdens novoorstellingen in het verleden moet hebben geheerst. De hoofdrolspeler die langzaam zijn entree maakte, opdoemend uit het halfduister van de brug naar het hoofdpodium, met de overvloed aan met goud, zilver en contrasterende kleuren versierde stoffen glinsterend in het gedempte licht.

- Te zien in het Paviljoen van het Rijksmuseum, vanaf 2I oktober 2016 